\title{
ŻYD, ARAB. HISTORIA WROGA
}

\author{
GIL ANIDJAR
}

PRZEŁoŻyŁa: JoANNA BEDNAREK

Przekzad Przejrzata: Monika Bobako

\begin{abstract}
Abstrakt: Tekst jest fragmentem książki The Jew, The Arab. A History of the Enemy poświęconej historii wrogości między Arabami i Żydami, a także historii związku tego konfliktu z kształtowaniem się zarówno tożsamości w Europie, jak i tożsamości samych Arabów i Żydów. Śledząc rozważania takich filozofów jak Carl Schmitt czy Jacques Derrida, autor stara się przedstawić mechanizmy odpowiedzialne za tworzenie różnic pierwotnych względem tożsamości i jednocześnie dla ich konstrukcji niezbędnych. Różnice te są niezbędne do tworzenia par pojęciowych takich jak „wnętrze-zewnętrze” czy „wróg-przyjaciel”. Problem konstrukcji pojęcia wroga jako konstrukcji różnic i tożsamości zostaje tu zbadany na płaszczyźnie teologii, polityki i prawa, a także jako zagadnienie związane z różnicami etnicznymi oraz z pojęciem „Europy”.
\end{abstract}

Słowa kluczowe: antysemityzm, islamofobia, kolonializm, różnica, Europa, orientalizm, Derrida, teologia, prawo 


\section{Przedmowa ${ }^{1}$}

Powinno stać się jasne, że książka Żyd, Arab. Historia wroga² dotyczy Europy, która jest tej książki zarazem granicą i ograniczeniem.

A zatem Europa i dotyczące jej następujące pytania: czy istnieje w ogóle coś takiego jak pojęcie wroga? A jeśli istnieje, to do jakiej sfery dyskursywnej (polityki, teologii, prawa, filozofii, psychoanalizy) należy? Którą z nich określa? Albo - a w oscylacjach tego „albo” mieści się wszystko, co nastąpi później - jeśli pojęcie wroga nie istnieje, jeśli należy je dopiero sformułować (albo po prostu pomyśleć), to jakie czynniki nie dopuściły do jego sformułowania? Jedna z możliwych odpowiedzi na to pytanie (mówiąca nam też co nieco na temat pytań poprzednich), prezentowana tutaj, głosi, że wróg - pojmowany jako konkretne, dyskursywne, zanikające pole, „cień odwiecznego ducha” (Derrida 1994/2005), jak ujmuje to Derrida - ustrukturyzowany jest przez Araba i Żyda, czyli przez relację łączącą Europę jednocześnie z Arabem i Żydem. Druga możliwa odpowiedź głosi, że strukturyzacja ta wiąże się mocno z religią i polityką. Wyzwanie, które te dwie, z pewnością niewystarczające odpowiedzi rzucają aż nazbyt licznym pytaniom, polegać będzie na próbie wykazania, że w Europie, w „chrześcijańskiej Europie” są oni, one - Żyd, Arab z jednej strony, religia i polityka zaś z drugiej - czymś możliwym do odróżnienia, ale nierozdzielnym. Ujmując rzecz inaczej: Żyd, Arab stanowią warunek możliwości religii i polityki.

\section{Wprowadzenie: momenty teologiczno-polityczne}

moment z łac. momentum: od: movere - poruszać się; siła poruszająca; przyczyna; wpływ; znaczenie; języczek u wagi; przewaga; odcinek czasu odczuwany jako bardzo krótki; najmniejsza jednostka czasu, chwila; punkt w czasie wyodrębniany w psychice człowieka ze względu na pewne zdarzenie; krótki etap w trwaniu lub rozwoju czegoś; wielkość służąca do opisu właściwości fizycznych obiektów w mechanice: moment obrotowy, statyczny; moment siły, pędu.

Merriam-Webster's Dictionary/Wielki stownik jezyka polskiego/Lingua Latina Omnibus ${ }^{3}$

1 Tekst przetłumaczony w ramach projektu badawczego sfinansowanego ze środków Narodowego Centrum Nauki przyznanych na podstawie decyzji numer DEC-2011/03/B/HS1/01693.

2 Tekst jest fragmentem książi The Jew, The Arab. A History of the Enemy (2003).

${ }^{3}$ Hasło z Merriam-Webster's Dictionary stanowiące motto do tekstu w dosłownym przekładzie nie miałoby wiele sensu, ponieważ zakres znaczeniowy słowa „moment” w języki angielskim jest inny niż w języku polskim. Dlatego zdecydowałam się skompilować oryginalne hasło z hasłem ,moment” z Wielkiego stownika jezyka polskiego Instytutu Języka Polskiego PAN http://www.wsjp.pl/do_druku.php?id_hasla=23117\&id_znaczenia=0, 
Spróbujmy zatem określić, jakie zdarzenia są zdolne obudzić w nas przerażenie, a jakie wzruszenie. Tego rodzaju akcja musi z natury rzeczy rozgrywać się bądź między osobami bardzo sobie bliskimi, bądź wrogami lub też między osobami, których nie łączy ani przyjaźń, ani wrogość. Jeśli więc wróg wystapi przeciw wrogowi, to ani sam jego czyn, ani też zamiar wykonania tego czynu nie wzbudzi litości, lecz może ją wzbudzić cierpienie. (Arystoteles 1988, 337)

W niniejszej książce zajmuję się tym, jak wróg staje się wrogiem - historia wroga wpisana w obręb i pomiędzy spolaryzowane tożsamości Żyda i Araba. O ile rzeczywiście tworzy ona jakąs historię, to jest to historia dłuższa niż ta kolonialna, jakkolwiek jej kolonialne aspekty wpływ czy wręcz założycielska i podtrzymująca rola, jaką brytyjski kolonializm i amerykański imperializm, by wymienić tylko dwóch głównych aktorów, odegrały w stworzeniu i kontynuacji „konfliktu bliskowschodniego” - są być może lepiej opisane, chociaż niekoniecznie lepiej zrozumiane. Żyd, Arab. Historia wroga jest jednak również mniej niż historia - mniej historia, bardziej zaś wstępnym wyjaśnieniem, dlaczego ta historia nie została napisana.

Co, poza przerażająco znajomym i nieuniknionym „cyklem przemocy”, podtrzymuje dystans i budzi wrogość między Arabem i Żydem? Jakim celom, jakim racjom służy naturalizowanie tego przeciwstawienia, tej wrogości, która, jak chca narracje dominujące, narodziła się już w starożytnych czasach biblijnych, stanowiąc nieodłączne dziedzictwo Bliskiego Wschodu, regionu i ziemi odwiecznie pustoszonej przez wojnę i konflikty? Jak to się stało, że te rzucające się w oczy znaczniki tożsamościowe, Arab (znacznik „etniczny”) i Żyd (znacznik „religijny”), tak silnie wpisały się w najróżniejsze nowoczesne dyskursy - polityczne, religijne, kulturowe itd. - towarzysząc różnorodnym, często wręcz przeciwstawnym celom politycznym, a także ostrożnym i zniuansowanym podejściom krytycznym i demistyfikacyjnym ${ }^{4}$ ?

dostęp: 23.06.2016) i hasłem „momentum” z Lingua Latina Omnibus

(http://www.lacina.info.pl/index.php?dzial=slowniczek\&opcja=slownik, dostęp: 23.06.2016) [przyp. tłum.].

${ }^{4}$ Wahania i niepewność co do „właściwych” określeń opisujących przeszłość i teraźniejszość sytuacji w Izraelu/Palestynie są dobrze znane i wiele mówią na temat celów, którym służy, świadomie bądź nie, każdy z wyborów. Kim są właściwie przeciwnicy? Izraelczykami i Palestyńczykami? Żydami i muzułmanami? Żydami i Arabami? Politycznymi realistami i religijnymi ekstremistami? „Żyd” i „Arab” pozostają określeniami dominującymi, choćby dlatego, że są to terminy umieszczone na izraelskich dowodach osobistych i dlatego maja wpływ na codzienne życie milionów ludzi. Żyd i Arab pojawiają się tu przed prawem i jako „narodowości”, a więc w ramach kategorii innej niż „obywatelstwo”, które jest zawsze „izraelskie”. (Zauważmy, że „Żyd” podlega tu odteologicznieniu, podczas gdy „Arab” pozostaje niezależny od wszelkich kontekstów religijnych, będąc oznaczeniem etnicznym, politycznym.) Bernard Lewis rekonstruuje, w zbliżonym kontekście, wschodnioeuropejska genealogię rozróżnienia między narodowością (czyli narodowością jako etnicznościa) oraz obywatelstwem. Wskazuje również, że instytucjonalizacja tego rozróżnienia zakładała przekształcenie religii w etniczność (w tym przypadku „Żyda”) i ograniczenie znaczenia, wręcz wymazanie religii jako kategorii tożsamościowej („Arab” zastępuje „muzułmanina” lub „chrześcijanina”). Rolę, jaką odgrywa ta „,́wiecka” instytucja pozostawiająca religię za soba, wywodzi Lewis z historii Związu Radzieckiego. Pragmatyczne, jeśli nie historyczne powody stojące za tą rolą rozjaśnia jego komentarz: „,narodowości opartej na etniczności nie można, w przeciwieństwie do religii, zmienić, nawracając się” (Lewis 1999, 34). Dlatego gdy mówimy o „Izraelczykach 
Prawo stanowi być może najważniejszą instytucję, za pomoca której państwo kolonialne zarządzało w dziewiętnastym i dwudziestym wieku swoimi populacjami. Jak ujmuje to Mahmood Mamdani, ,jedno założenie określiło wspólny projekt cywilizacyjny: rządzący i rządzeni, ludzie Zachodu i ci spoza Zachodu, wszyscy poddani władzy państwowej maja podlegać importowanemu zachodniemu prawu" (Mamdani 2001, 24) ${ }^{5}$. W obrębie tego systemu prawnego państwo wdraża „mechanizmy represyjne i produktywne”, przyczyniające się do stworzenia „nowości jako tego, co istniało od zawsze” (Massad 2001, 4). Jednym z tych mechanizmów, stanowiącym zarazem podstawę pozwalającą odróżnić kolonizatora i kolonizowanego oraz dokonywać dyskryminacji, była rasa. Dyskryminacja ta jednak nie wystarczała, stosowano zatem kolejne rozróżnienia, czasem jeszcze przed oficjalnym wprowadzeniem zachodniego prawa i pełną instytucjonalizacją rządów kolonialnych. Czasowość tych rozróżnień jest mniej istotna niż struktury, które pomogły one wdrożyć. $\mathrm{Na}$ jednym poziomie znajdujemy zatem „obecne w prawie cywilnym rasowe oddzielenie tubylców od nie-tubylców”, skolonizowanych od kolonizatorów. Na innym poziomie jednak sami tubylcy sa ,dzieleni [...] na grupy, a każda z tych grup podlega innemu zestawowi praw "zwyczajowych«".

i Palestyńczykach” (gdzie czynnikiem głównym jest nacjonalizm), „żydach i muzułmanach” (gdzie takim czynnikiem jest religia), czy „Żydach i Arabach” (co oznacza przeciwstawienie umiarkowanej, tzw. demokratycznej polityki „fanatycznej” religii), nie mylimy się po prostu, ale podtrzymujemy stanowisko, zinstytucjonalizowane przez państwo izraelskie, które odtwarza niewidzialne czy też niekwestionowane podziały - zewnętrzne i wewnętrzne - między religią i polityką oraz „Żydami” i „Arabami”, a także wewnątrz nich.

Należy tu podkreślić, że, poza krótkimi dygresjami Izrael i Palestyna nie będą bezpośrednio zajmować znaczącego miejsca w tej książce; mimo to można ją moim zdaniem uznać za skromny komentarz do badań prowadzonych, przede wszystkim, przez Amnona Raza-Krakotzkina, którym zawdzięczam bardzo wiele. W odniesieniu do poruszanej tu problematyki Raz-Krakotzkin zaproponowal oryginalne przekształcenie kategorii dwunarodowości (zapożyczonej częściowo od Hannah Arendt), w celu uniknięcia tego, co stanowi obecnie przedmiot powszechnego konsensusu znajdującego się już w centrum Porozumień z Oslo: oddzielenia. Oddzielenie to, jak wyjaśnia Raz-Krakotzkin, jest inną nazwą dla „autonomii, której funkcją jest odseparowanie Palestyńczyków od Żydów" (Raz-Krakotzkin 1998, 66). Odtwarza ono również rodzaj historii, którą usiłuję opisać w tej książce, i dąży do utrwalenia jej.

Ujmując to inaczej i bardziej zdecydowanie, oddzielenie to miało miejsce już wtedy, gdy „Tel Awiw stał się jedynym zachodnim miastem, do którego zabroniono wstępu Arabom. Podejście towarzyszace procesowi pokojowemu można więc uznać za pod wieloma względami bliskie podejściu europejskiej radykalnej prawicy: przed zawarciem Porozumień z Oslo i po nich podjęto kroki tożsame z tymi postulowanymi przez Le Pena i jego zwolenników" (Raz-Krakotzkin 1998, 67). W debacie o tak powszechnie akceptowanych współrzędnych brakuje „możliwego do pomyślenia stanowiska politycznego, mogącego połączyć perspektywę tożsamości izraelskożydowskiej z perspektywą praw Palestyńczyków" (Raz-Krakotzkin 1998, 75). Brakuje krytycznego przyjrzenia się świadomości historycznej i kwestii interpretacji historycznej (68-69), którą Raz-Krakotzkin określa jako „podejście dwunarodowe, takie, które nie oddzielałoby dyskusji na temat społeczeństwa izraelskiego od konfliktu izraelsko-palestyńskiego (75). Jak ujmuje to w innym miejscu, dwunarodowość „zakłada uświadomienie sobie, że palestyńska historia i tożsamość narodowa należa do debaty na temat historii syjonistycznej, stanowiąc nieodłączną część kontekstu odpowiedzialności. Definicja praw Palestyńczyków i praw Żydów to jedno i to samo. Oto kontekst odpowiedzialności stworzony przez syjonizm [...]. Perspektywa dwunarodowa prowadzi do [...] definicji wspólnej, arabsko-żydowskiej przestrzeni” (Raz-Krakotzkin 2002, 321; zob. też: Raz-Krakotzkin 2001).

5 Bliskie temu ujęciu omówienie roli prawa w wytwarzaniu „podmiotu prawnego będącego podłożem dystrybucji władzy" w kontekstach kolonialnych i postkolonialnych znajduje się w: Massad 2001, 22. 
Prawo ukonstytuowało zatem, oprócz rasy, inną, odrębną kategorię - „etniczność”. „Samą kategorię »tubylców« rozmontowano za pomocą środków prawnych, gdy różne grupy tubylców oddzielono od siebie na podstawie etniczności. Grupa etniczna przestała być zaledwie wspólnotą związana przez kulturę, a stała się wspólnotą polityczną". Odwołanie się do „miejscowych zwyczajów” stworzyło w obrębie (zachodniego) prawa sferę znajdującą się poza prawem, w obrębie prawa, a zarazem poza zasięgiem jego jurysdykcji, sferę rządzącą się innymi nakazami kulturowymi i politycznymi. „W obrębie jednego porządku prawnego” wyłoniły się różnice etniczne, czyli znaturalizowane różnice polityczne. ,J Jezyk prawa dążył do znaturalizowania politycznych różnic obecnych na terenie kolonii, rozkładając je na drabinie postępu cywilizacyjnego. Prawo, stosując test postępu, oddzielało cywilizowana mniejszość od jeszcze-nie-ucywilizowanej większości, obejmując tę mniejszość porządkiem prawa, z którego większość była wykluczona" (Mamdani 2001, 25) ${ }^{6}$.

Należy zatem skupić się na sposobie funkcjonowania rozróżnienia między rasą i etnicznościa, będącego przede wszystkim rozróżnieniem prawnym, za pomoca którego populacja zostaje zarazem włączona (poddając się prawu zachodniemu) i wyłączona (uznana przez samo prawo za znajdująca się na zewnątrz prawa), podlegając innemu zestawowi praw, określanych jako „zwyczajowe”. Państwo kolonialne i zachodnie prawo wytwarzały różnice polityczne wewnątrz skolonizowanej populacji, naturalizowały jednak te różnice jako kulturowe lub etniczne. W obrębie jednego systemu prawnego i jednej skolonizowanej populacji wyłoniły się więc wewnętrzne różnice między etnicznością i rasa, większością i mniejszością, tubylcami i nie-tubylcami (Mamdani 2001, 26-27).

Mamdani, opisując reżim podziałów ustanowiony w Afryce, wyjaśnia, że urasowione mniejszości wyniesione ponad większość skolonizowanych definiowane były jako „rasy podporządkowane". Odróżniano je od większości skolonizowanych jako nie-tubylcze i nadawano im status ,prawie obywateli”. Ich przedstawiciele byli

pozbawieni praw związanych z obywatelstwem, jednak uznawano ich za posiadających potencjał stania się kiedyś prawdziwymi obywatelami. Choć skolonizowani, mogli zajmować niższe stanowiska urzędnicze w machinie misji cywilizacyjnej. Nie należąc do

\footnotetext{
${ }^{6} \mathrm{~W}$ tej kwestii zob. też Colonial Effects Massada, gdzie pojawia się opis podobnych procesów odróżniania prawa cywilnego i plemiennego w Jordanii, procesów, które między 1921 i 1976 rokiem doprowadziły do sytuacji, w której „wszyscy Beduini sa pozornie równi wobec prawa ustanowionego przez kodeks cywilny, ale prawo plemienne uznaje ich za odmiennych” (Massad 2001, 50). W wyniku nacisków brytyjskich Beduini „podlegali innemu systemowi prawnemu już w październiku 1924 roku, kiedy to państwo Mandatowo-Haszymidzkie wprowadziło Ustawę o Sądach Plemiennych" (Massad 2001, 52; zob. też 56-66). Massad analizuje następnie związki między tym podziałem a rozróżnieniem na to, co tradycyjne, i to, co nowoczesne. Omawia też zmniejszenie terytorium Beduinów oraz ich rolę $\mathrm{w}$ fantazjach historycznych, turystyce oraz organach egzekwowania prawa (wojsku i policji).
} 
kolonizatorów, zostali zintegrowani z maszynerią kolonialnych rządów jako pośrednicy w obrębie aparatu państwowego czy rynku. Dlatego postrzegano ich jako narzędzia kolonializmu i tych, którzy na nim korzystali, niezależnie od tego, jak wymuszona była ich współpraca i jak skromne korzyści z niej płynące. Rasy podporządkowane, choć należały do skolonizowanej populacji, były traktowane preferencyjnie przez prawo. Etniczności podporządkowane, przeciwnie, były oddzielane i w majestacie prawa uciskane (Mamdani 2001, 27).

W Afryce, jak wyjaśnia Mamdani, istniało wiele ras podporządkowanych. Ich lista obejmuje Azjatów mieszkających w Afryce Wschodniej, Hindusów oraz „Kolorowych” z Afryki Południowej, Arabów z Zanzibaru i oczywiście Tutsi z Rwandy i Burundi (Mamdani 2001, 28). Przerażająca historia podziałów politycznych, które, znaturalizowane przez rządy kolonialne, utrwaliły się w postaci różnic kulturowych, prowadzących później do tego, co nazywano „przemocą na tle etnicznym” w Rwandzie, zostaje przez niego opisana i, co więcej, zbadana i wyjaśniona. Władza kolonialna wytworzyła tożsamości polityczne, do naturalizacji których dążyła. Proces, który pozostał w większej części niemal niedostrzegalny, doprowadził do tego, że „Tutsi zostali skonstruowani jako nie-tubylczy Chamici”, odrębna „rasa [...] zarazem cywilizująca i obca" (Mamdani 2001, 28, 89).

Tak zwana hipoteza chamicka ${ }^{7}$ stanowiła część rozbudowanego aparatu ideologicznego, którego celem było „przekształcenie Tutsi, »urodzonych władców« Rwandy, w elitę »zdolną do zrozumienia i realizowania postępu«, a więc służącą jako pomocnicy misjonarzy i administracji kolonialnej”. Stworzono system szkolnictwa, „mogacy funkcjonować jako macierz rasistowskiej ideologii”. Tutsi zatem „otrzymywali »lepsząu edukację, prowadzoną w języku francuskim. Asymilacjonistyczna edukacja przygotowywała ich do pełnienia funkcji administracyjnych w aparacie państwowym i stanowiła świadectwo ich zdolności do zdobycia obywatelstwa, nawet jeśli miałoby to być obywatelstwo najniższego typu” (Mamdani 2001, 90). Podobnie jak Żydzi z Algierii (którym przyznano, wyjątkowo, obywatelstwo w 1870 roku

\footnotetext{
${ }^{7}$ Nazwa pochodzi do Chama, jednego z synów Noego. Zaproponowana w połowie dziewiętnastego wieku przez kilku antropologów hipoteza, zgodnie z którą w Afryce można wyodrębnić osobną rasę, „wyższą” od rasy negroidalnej. Jej zwolennicy wiązali biblijną opowieść o wędrówkach synów Noego z rzekomą migracją podgrupy „,rasy kaukaskiej” na tereny Afryki. Tutsi i Masajowie mieli być ich zdaniem częściowo pochodzenia chamickiego [przyp. tłum.].

${ }^{8}$ André Choraqui wyjaśnia, że fundamentalna zmiana w obrębie algierskiej populacji zaszła już z chwila wejścia w życie aktu kapitulacji z 5 lipca 1839 roku, który ustanowił rządy francuskie. Akt ten „zakładał likwidację tradycyjnych relacji między muzułmanami a Żydami. Różnica między tymi dwiema grupami została jednak podtrzymana, nie w oparciu o religię, ale w oparciu o narodowość" (Choraqui 1973, 143). Nie rozwija on refleksji nad nowym podziałem prawno-politycznym między narodowością i obywatelstwem, ale opisuje, jak religia nadal określała sytuacje prawną Żydów - do roku 1870. „Sądom rabinicznym powierzano wymierzanie sprawiedliwości” (144). W roku 1934 Francuzi uznali je jednak za „niezadowalające”, a wraz z dekretem Crémieux „Żydów będących rdzennymi mieszkańcami Algierii uznaje się za obywateli Francji. W konsekwencji ich status prawny i cywilny podlega regulacjom prawa francuskiego" (dekret z 24 października 1870 roku, za: Choraqui 1973, 150). Więcej informacji o historii algierskich Żydów i roli Alliance Israélite Universelle we francuskiej „misji
} 
dzięki czemu stali się oni symbolem obietnicy mamiącej Żydów z całego świata arabskiego, obietnicy sumiennie podtrzymywanej, nawet jeśli do jej spełnienia było daleko, przez Alliance Israélite Universelle) Tutsi stali się nie-tubylczymi outsiderami, polityczną mniejszością nienależącą do tubylczej wspólnoty. Stali się wrogami wewnętrznymi.

Mamdani sugeruje, że aby zrozumieć ludobójstwo w Rwandzie, „wynikające z tego, że możliwe stało się nie tylko oddzielenie danej grupy jako wroga, ale i jej eksterminacja bez wyrzutów sumienia” (Mamdani 2001, 13), należy zwrócić uwagę na to, iż zarówno rasa, jak i etniczność są politycznymi wynalazkami, osadem złożonych procesów prawnych. Wzywa do „zrozumienia dynamiki prowadzącej do polaryzacji tożsamości politycznych” (23), które są „podtrzymywane przez prawo i odtwarzane przez instytucje” (15) i które nie istniały (w żaden porównywalny sposób) przed nastaniem rządów kolonialnych. Choć każdy system kulturowy posługuje się rozróżnieniami, mogą one zawsze podlegać fluktuacjom i zmianom, „przechodzić w siebie nawzajem, poruszać się po terenie pośrednim, pozwalającym na zaistnienie hybrydyczności i niejednoznaczności” (23). Ale w obrębie polaryzacji stwarzanej przez władzę kolonialną „nie ma terenów pośrednich, nie ma kontinuum łączącego spolaryzowane tożsamości. Wytwarzają one różnicę polityczna, nakazująca być albo jednym, albo drugim. Nie można należeć do obydwu kategorii. Różnica staje się opozycją binarną, działającą nie tylko w prawie, ale i w codziennym życiu. Nie dopuszcza ona wieloznaczności” (Mamdani 2001, 23).

Dzięki rozstrzygającej argumentacji Mamdaniego wiemy, na czym polegała polaryzacja Hutu i Tutsi w wymiarze politycznym, rasowym i etnicznym. Autor ten odsłania jednak też jeszcze inny obszar refleksji, kiedy pyta o przyszłość Rwandy po ludobójstwie. Stosując dość enigmatyczną analogię, stawia następujące pytania: „Czy Rwanda pójdzie w ślady Izraela i stworzy odrębną wspólnotę Tutsi obok wspólnoty Hutu? ${ }^{9}$ Czy też pójdzie w ślady Zanzibaru i stworzy szerszą wspólnotę, mającą tendencję do rozpuszczania spolaryzowanych tożsamości politycznych [...] w przestrzeni wypełnionej wielorakimi tożsamościami? Czy też wybierze trzeci kierunek [...], próbując ukształtować tożsamość polityczną przekraczająca partykularność tożsamości Hutu i Tutsi?” (Mamdani 2001, 265). Pytania te, mimo ogromnych

cywilizacyjnej" można znaleźć w: Halevi 1987; Derrida 1996. Jednym z paradoksów historii jest to, że algierskich Żydów uznaje się często za potomków kolonistów francuskich, pieds-noirs, nie zaś za tych, którymi w swej większości byli - rdzennych mieszkańców Algierii. Pewna liczba Żydów europejskich, pochodzących głównie z Alzacji-Lotaryngii, pojawiła się wprawdzie w Algierii po wojnie francusko-pruskiej z 1870 roku, jednak nawet miejscowe francuskie władze nie zwróciły uwagi na tę imigrację i traktowały Żydów nadal jako rdzennych mieszkańców, przypominając im o tym fakcie na przykład na formularzach spisów ludności. Dlatego do roku 1931 oficjalne formularze nadal zawierały pytanie, czy otrzymało się obywatelstwo dzięki dekretowi Crémieux albo było potomkiem kogoś, kto je otrzymał („Etes-vous israélite naturalisé par le decrét de 1870 ou issu d'un israélite naturalisé par ce decrét?', za: Allouche-Benayoun i Bensimon 1997).

${ }^{9}$ Fakt, że termin „,wróg” nie pojawia się w indeksie książki Mamdaniego, nie jest rzeczą zupełnie trywialna. Nie pojawia się tam też termin „Izrael”. Choć żadne z tych przeoczeń nie jest przypadkowe i prawdopodobnie każde z nich ma swoje powody, są one godne ubolewania, ponieważ to, co Mamdani mówi o obydwu „terminach”, stanowi kluczowy aspekt jego argumentacji i ważny wkład w problematykę, która się z nimi wiąże. 
trudności związanych z tego typu uogólnieniami, a przede wszystkim z takim porównaniami (pomińmy na razie kwestię pełnego przemocy procesu, za sprawą którego europejscy Żydzi stali się osadnikami-kolonizatorami, jak również kwestię ciagłości między antysemityzmem i syjonizmem oraz kwestię tego, co łączy kolonialne dzieje Europy z kolonizacja palestyńskich Arabów przez europejskich Żydów), są kłopotliwe, lecz konieczne. Kto w Izraelu i Palestynie jest Hutu, a kto Tutsi? Jakie historyczne, prawne, religijne i polityczne procesy znaturalizowały Żyda i Araba jako spolaryzowane tożsamości? Mamdani, choć nie stosuje tego terminu jako głównego pojęcia operacyjnego swoich dociekań, podkreśla, że odpowiedź na te pytania musi zmierzyć się z zagadnieniem - i historia - wroga: „Zanim spróbujemy zlikwidować wroga”, jak pisze, „trzeba go najpierw zidentyfikować. Definicje politycznego podmiotu i jego innego zmieniały się w toku dziejów. Historia tych zmian to historia tożsamości politycznych, religijnych, narodowych, rasowych czy innych” (Mamdani 2001, 9). Problem wroga wyłania się i powraca tu jako historia tożsamości politycznych, jako, być może, historia samej polityczności. Jak w tym konkretnym przypadku, na przykład, stało się możliwe ,nie tylko oddzielenie danej grupy jako wroga, ale i jej eksterminacja bez wyrzutów sumienia” (13)? I dlaczego morderstwa popełnione w Rwandzie „pozostają wymierzone głównie w tych, których określono jako wrogów politycznych, nie zaś wrogów klasowych” (194)? Jakie warunki umożliwiły „prawdziwie przerażający aspekt tego ludobójstwa”, czyli fakt, że „definicja wroga stała się wiarygodna dla wielu zwykłych Hutu” (202)? Jak historia doprowadziła do wyłonienia się „wroga wewnętrznego”, który szybko przekształcił się w outsidera; wroga z którym należało walczyć, którego należało wygnać, a w końcu wymordować? W jaki sposób krystalizowanie się tożsamości politycznych wytwarza tak przerażające skutki? Podobnie jak Straż Prezydencka Hutu, sami Hutu przeszli od „mierzenia się z wrogiem, który wydawał się dokonywać bezlitosnej ofensywy na polu bitwy czy też na froncie dyplomatycznym”, do „mierzenia się z wrogiem wewnętrznym” (207). Jednak wróg ten nie istniał tak po prostu, czekając na konfrontację. Należało go znaleźć, należało go szukać. Odwrócili się zatem „od wroga na polu bitwy [...] i zaczęli szukać wroga pomiędzy sobą" (215).

$\mathrm{Na}$ wczesnym etapie swojej argumentacji Mamdani przypomina, że „Europa »poradziła sobie« ze swoim kryzysem politycznym, eksportując go na Bliski Wschód” (39). Jest to z pewnością prawda. Ale czym właściwie była, czym nadal jest Europa, że musiała jakoś poradzić sobie z tym konkretnym kryzysem? I co to ma wspólnego z Żydami i Arabami? Większość dotychczasowych analiz koncentruje się na owym eksporcie „kwestii żydowskiej”, uznając wybór arabskiej Palestyny za przygodny wybór europejskiego kolonializmu albo za skutek syjonistycznych aspiracji. Inne ważne analizy skupiają się na przekształceniach samej historii konfliktu ,islamu i Zachodu”. Ujmując to nieco schematycznie, powiedzieć możemy, że analizy pierwszego typu zwracaja uwagę na antysemityzm, analizy drugiego typu zaś na orientalizm. Nie umniejszając znaczenia tych perspektyw, ani też znaczenia niesprawiedliwości związanych 
ze zmuszaniem Palestyńczyków, by płacili za winę Europy wobec Żydów, należy zauważyć, że obydwa typy analiz traktuja jako oczywiste istniejące stany wrogości (między Żydami i Arabami, między Europa i Arabami, Europa i Żydami, w tym ostatnim przypadku związane z winą nie do odkupienia), nie biorąc pod uwagę możliwości istnienia ukrytych powiązań i jawnych połączeń między członami tych opozycji ${ }^{10}$. Jako że wanalizach tych rezygnuje się z rozpatrywania trzech „elementów” (Żyda, Araba, Europy) równocześnie, porzuca się w nich tym samym zamiar wyjaśnienia historycznego problemu, jaki stanowi wrogość.

W tego rodzaju analizach zakłada się na przykład, bez żadnego wahania, oddzielenie dwóch zbitek: „Europa i Żydzi” oraz „islam i Zachód” (by przywołać dwa najsłynniejsze hasła), a także utrwala się stałość „,idei” Europy (nieodmiennie kruchej tak w przeszłości, jak i obecnie, niezależnie od najbrutalniejszych momentów wymuszania jej tożsamości), idei, która miałaby istnieć niezależnie od konstytutywnej relacji z Żydami i/albo Arabami. Ujęcia te traktuja jako oczywistą również dychotomię Araba i Żyda jako dwóch spolaryzowanych tożsamości, ukonstytuowanych niezależnie od siebie. Rzecz jasna nie ma sensu zaprzeczać, że ujęcia takie są możliwe, uprawnione, a nawet że należy je rozwijać. Można je także uzupełnić badaniami korygującymi zawarte w nich tezy, skupiającymi się na kulturze śródziemnomorskiej lub trzech wielkich religiach monoteistycznych, pojmowanych jako swego rodzaju jednostki. Nie sposób jednak nie odczuwać zdziwienia z powodu braku jakichkolwiek wzmianek, braku solidnych analiz, a nawet jakiejkolwiek historii „Europy” rozpatrywanej w odniesieniu do Żyda i Araba jednocześnie.

Sugerując, że wyłącznie „kwestia żydowska” - a nie „kwestia arabska” - została wyeksportowana z Europy, pozbawiamy się możliwości wypracowania innego ujęcia Europy. Co więcej, naturalizujemy oraz oddzielamy antysemityzm i orientalizm w ich swoistych, anachronicznych postaciach historycznych, a co jeszcze ważniejsze, traktujemy „Żyda” i „Araba” jako kategorie, które po prostu istnieja i - poza kilkoma wyjątkami, by nie rzec anomaliami („średniowieczna Hiszpania”; „Bośnia i Hercegowina”) - mają zupełnie odrębne, hermetyczne historie. Idzie tu o coś więcej niż tylko uzupełnienie danych historycznych na temat Arabów i Żydów pojmowanych jako odrębni i zewnętrzni wobec „chrześcijańskiego Zachodu” (czy faktycznie żyli ze sobą w zgodzie? Czy byli do tego zdolni? Dlaczego się nienawidzili/nienawidzą? I dlaczego nienawidzą nas? Czy było to pokojowe współistnienie? Jaki był ich rzeczywisty wkład w filozofię, naukę, cywilizację? I co stało się później? I tak dalej, i tak dalej...). Nie chodzi też - czy naprawdę trzeba to mówić? - o przekonywanie, że walka

\footnotetext{
10 Podobna argumentacja, która łączy rasizm i antysemityzm - choć na sposób inny niż ten przedstawiany tutaj - jako coś, co współkonstytuuje Europę na „spodniej stronie” jej pojęć, a być może także i to, co jest w niej pozapojęciowe, zawarta jest w: David 2001. David również inspiruje się pracami Derridy i podkreśla istotność zanikania, ,niepokojącego constat wymazywania rasizmu i antysemityzmu z porządku pojęć” (David 2001, 50), nieobecności czy też wycofania czegoś, co można by przetłumaczyć jako pojęcie wroga (96, przypis 111 i $112-$ 113).
} 
ta toczy się nie między dwiema (lub trzema) stronami, ale wewnątrz jednej strony, że nie należy wyodrębniać i podtrzymywać żadnych różnic. Sam sposób sformułowania pytania, a co więcej, sama refleksja nad jego konstytutywnymi elementami narzuca nam rozpatrywanie Żyda i Araba oraz ich „miejsca” w Europie niezależnie od ich wzajemnych relacji. (Jeśli, na przykład, chodzi o nas i o nich, to głównym problemem pozostaje wspólne wyłanianie się, a nie tożsamość nasza czy ich.) Podejście to nie wystarcza do ujęcia obecnego stanu rzeczy (tak zwanych „działań na rzecz pokoju” potęg zachodnich na Bliskim Wschodzie, jak również „porażek” tych działań), ani też do zrozumienia sposobu, w jaki te dwie tożsamości polityczne - Żyd, Arab - ukonstytuowały się dzięki, a przede wszystkim z Europą i w obrębie Europy. Pytanie, które usiłuję zadać w tej książce, brzmi więc: czym jest Europa? Czym jest jako byt, któremu udało się nie tylko odróżnić siebie od Żyda i Araba, ale także uczynić niewidzialną swoją rolę w odróżnieniu, oddzieleniu i wzbudzeniu wrogości między Żydami i Arabami - niewidzialna, być może, głównie dla samej Europy? Innymi słowy: w jaki sposób historia wroga stała się historią niemożliwą?

\section{Europa}

Banalność (w sensie Hannah Arendt) kolejnego podziału: Europa, tak zwana „chrześcijańska Europa”, dzieli się od samego początku na wroga wewnętrznego i wroga zewnętrznego. „Chrześcijaństwo równa się Zachodowi” pisze Jean-Luc Nancy, „równa się pewnemu procesowi westernizacji, polegającemu na swego rodzaju samo-wchłanianiu i samoprzezwyciężaniu” (Nancy 1998/2001). Innymi słowy, chrześcijaństwo pojmowane jako Europa naznaczone jest wewnętrznym konfliktem, „przyjmującym postać schizofrenii lub wewnętrznego pęknięcia” (117). To właśnie w odniesieniu do tego chrześcijaństwa, tej Europy, Nancy zastanawia się, „dlaczego nasze spojrzenie wydaje się systematycznie od nich odwracać [...], zupełnie tak, jakbyśmy nie chcieli spojrzeć chrześcijaninowi w twarz"; tę Europę, to chrześcijaństwo, określa Nancy jako „tę właśnie rzecz - rzecz samą - którą należy przemyśleć” (113).

Nancy naświetla pęknięcie Europy, kwestionując jego zewnętrzny charakter, zwracając uwagę na historię jego „stawania-się-wewnętrznym”. Jak twierdzi, „wewnętrzny konflikt” Europy, „(będący dziś wewnętrznym konfliktem judaizmu i chrześcijaństwa, choć w całkiem inny sposób), nie ma nic wspólnego z konfliktem [...] między chrześcijaństwem i judaizmem, ani też z konfliktami istniejącymi między wszystkimi wielkimi religiami”. Dlatego Nancy definiuje nasze zadanie jako refleksję nad „,wewnętrznym pęknięciem”. Jak jednak wyjaśnia, jego wewnętrzny charakter stanowi skutek historii - którą Nancy nazywa „możliwością jego stawania się" - stawania-się-wewnętrznym konfliktu Europy oraz zachowywania [przez nią] pewnego typu integralności. „W samym sercu chrześcijaństwa usytuowany jest szczególny 
rodzaj konfliktu, który można najtrafniej określić jako konflikt między integralnością i jej dezintegracją" (117). Owo zadanie refleksji, polegające, jak ujmuje to Denis Guénoun, na „myśleniu Europy na sposób podwójny”, musi zatem zmierzyć się z pęknięciem Europy, z jej podwójną innościa - jeśli rzeczywiście chodzi tu o inność. To wewnętrzne pęknięcie przestrzeni (Europy) na zewnętrzność i wewnętrzność jest konstytutywne dla niej, dla „możliwości jej stawania się”, które zawsze podlega de-konstytucji11.

Europa to nazwa. A nazwa, nazwa pospolita, która jest, jak sugeruje Guénoun w swojej niezwykłej książce Hypothèses sur l'Europe [„Hipotezy na temat Europy”], konstytuowana jest jako miejsce uczęszczane, miejsce wspólne będące zarazem miejscem pęknięcia, oddzielenia. Guénoun wykorzystuje logikę, która, w jej postaci sformalizowanej przez Derridę w Innym kursie, strukturyzuja dwa „aksjomaty”. Po pierwsze, Europa wspiera się na poczuciu, że, jak mówi Derrida, „jesteśmy młodsi niż kiedykolwiek, my Europejczycy, ponieważ rozumiana w określony sposób Europa jeszcze nie istnieje. Czy kiedykolwiek istniała?” (Derrida 2017, 14). Po drugie: „właściwością kultury jest nie być tożsamą ze sobą” (16). Tym, co należy przejąć z tej logiki oddzielenia i dystansu - jeśli rzeczywiście jest ona logika - jest to, że uczucie, które konstytuuje Europę, musi być trzymane na dystans, oddzielone od Europy, ku której zmierza, Europy, której istnienie zostaje tym samym podane w wattpliwość, zawieszone. Europa a zatem i „my, Europejczycy” - pozostaje w ten sposób oddzielona od siebie samej za sprawa uczucia, które nie potrafi upewnić się co do istnienia swojego obiektu. Przeciwstawiając się „idei Europy”, która jest, na przykład dla Edmunda Husserla, „poznawczym pewnikiem, narzucającym się w sposób oczywisty”, Derrida przywołuje to uczucie i stwierdza, że Europa „nie stanowi prawdy pewnej w sensie poznawczym” (Gasché 2000, 124). Istnienie Europy było i jest dość niepewne, ponieważ jej tożsamość, podobnie jak tożsamość każdej innej kultury, konstytuuje się - jako warunek możliwości i niemożliwości - poprzez nie-tożsamość ze soba.

Rodolphe Gasché zauważa, że ta nie-tożsamość jest podwojona, „podwójna ze swej istoty” (126). Po pierwsze, tożsamość kultury - tu: Europy - zakłada „różnicę zewnętrzną. Jest to różnica między kulturą a nią samą, wypływająca z nieustannego odnoszenia się przez daną kulturę do tożsamości innych kultur, wobec których i przeciwko którym ustanawia się każda tożsamość. Owe inne tożsamości kulturowe, będące tożsamościami Innych, mogą być po prostu odmienne od tożsamości europejskiej, ale mogą również stanowić jej przeciwieństwo" (126). Drugim warunkiem koniecznym każdej tożsamości kulturowej jest to, by tożsamość ta

${ }^{11}$ W „Above All, No Journalists!” Derrida dokonuje szczegółowego odczytania myśli Nancy’ego, za którym próbuję tu podążać; sugeruje on, że chrześcijaństwu bliska jest pokusa związana z wojną oraz [...] z wrogiem. Czy można myśleć o swoiście chrześcijańskiej historii wojny i wroga albo wręcz uznać, że ona istnieje? Pisząc, że „odczuwamy pokusę, by przyznać, że chrystianizacja jest zawsze w stanie wojny ze swoim przeciwieństwem”, Derrida, wraz z Nancym, uczula nas na dystans, który jest zarazem pokusą („odczuwamy pokusę”), między „,nami, Europejczykami” - zob. poniżej - i wojującym chrześcijaństwem, chrześcijaństwem jako wojną (Derrida 2001, 79). 
„była dodatkowo podzielona za pomocą różnicy wewnętrznej, auto-różnicy”, która „jest tym, co różni każdą tożsamość nie od stanu nie-tożsamości, z którego należy ja wydobyć, ale od »stanu« poprzedzającego różnicę miedzy tożsamością i nie-tożsamością" (126). Jak ujmuje to Derrida, „,nie ma relacji ze soba, identyfikacji ze soba, bez kultury, ale kultury siebie jako kultury innego $[\ldots]$, kultury podwójnego dopełniacza i różnicy względem siebie. Gramatyka podwójnego dopełniacza sygnalizuje również, że kultura nigdy nie ma jednego źródła. Monogenealogia zawsze byłaby więc mistyfikacją w historii kultury" (Derrida 2017, 16).

To między tymi dwoma gwałtownymi gestami otwarcia, dwoma warunkami możliwości i niemożliwości zarazem, co można także w upraszczający i niedokładny sposób określić jako rozróżnienie między warunkami empirycznymi i transcendentalnymi, Guénoun sytuuje Europę, wspólną nazwę i miejsce, które składają się na Europę, które wytwarzają i odtwarzają, jako współkonstytutywne, rozróżnienie czy wręcz przeciwstawienie tego, co teologiczne, i tego, co polityczne. „To, co teologiczno-polityczne”, jest, jak pisze Guénoun, „definitywnie miejscem różnicy teologiczno-politycznej” (Guénoun 2000, 58, przypis 87). Bada on następnie złożoną historię procesu, w toku którego coś, co nigdy nie było jednościa, zostaje ukonstytuowane, a potem ukonstytuowane powtórnie jako instytucjonalizacja cięcia („,cesarz nie będzie biskupem, Cezar nie będzie papieżem”; 52), które „ustanawia jednocześnie przestrzeń i oddzielenie, oddzielenie wpisane w interesującą nas tutaj wspólnotę jako wewnętrzne nacięcie, które nie pozostawia blizny” (52), „mimetyczną rywalizację Kościoła i Cesarstwa" (58), jak również pragnienie zjednoczenia tego, co teologiczne, i tego, co polityczne, a jednocześnie sprzeciw wobec tego zjednoczenia (108). Guénoun analizuje wewnętrzną różnicę każdego z tych terminów, stwierdzając na przykład, że to, co teologiczne, oraz to, co religijne, pojawia się jako różnica, czyli jako różnice zewnętrzne i wewnętrzne, dzięki którym „religia konstytuuje się jako różnica między religiami” (117).

Jednocześnie, jak dodaje Guénoun, to co polityczne, jest w swych wewnętrznych różnicach konstytuowane z podziałów religijnych (117, przypis 33) ${ }^{12}$. Wiąże on tym samym historię zmian politycznych w Europie z tym konkretnym podziałem, a więc z tym, co nazywa „różnicą teologiczno-polityczną”. W świetle tej historii naród wyłaniający się w toku Rewolucji Francuskiej jest „(teologiczno-polityczna) figurą odwróconego królestwa”, jak również „odwróconą figurą królestwa” (136). W figurze tej można dostrzec próbę zjednoczenia, a zatem wytworzenia ciała politycznego, które byłoby „polityczne i mistyczne zarazem”, próbę przekształcenia suwerenności w suwerenność ludu, zgromadzenia, nie zaś króla: „naród zajmuje szczególne miejsce w aparacie »teologiczno-politycznym«, którego historię usiłujemy tu przedstawić. Ukonstytuowany jako to, co się gromadzi (wytwarza to, co wspólne, to, czego

\footnotetext{
${ }^{12} \mathrm{~W}$ kwestii tego drugiego aspektu - konstytucji tego, co polityczne, z różnicy religijnej - Guénoun uznaje jedynie konieczny charakter stojącego przed nami zadania. Jak stwierdza, refleksja tego rodzaju wykracza poza zakres jego książki.
} 
byt jest wspólny), zajmuje miejsce kościoła, jeśli zechcemy przypomnieć sobie, że »kościól« to nic innego jak przekształcony termin na określenie zgromadzenia” (143). To, co stanowi być może najmocniejsze świadectwo sekularyzacji - co ukazuje Rewolucję Francuską jako deteologizację polityki - nie usuwa jednocześnie tego podziału, tej konstytutywnej teologicznopolitycznej struktury polityki. W kwestii żydowskiej Marks przedstawia tę porażkę w jasnym świetle, w słowach, które pozostaja aktualne do dziś. Jak pisze Guénoun: „Naród to idea teologiczna" (156).

We wcześniejszych partiach książki Guénoun dodaje jednak do opisywanych wyżej „aksjomatów” kolejny. Jak pisze: „Europa postrzega siebie jako stawiająca czoła islamowi” (62). Europa może więc dostrzec siebie tylko za pośrednictwem islamu. Stwarza ona dla siebie miejsce, z którego będzie mogła chronić siebie przed samą soba, przed tym, co wyprojektowała i wyobraziła sobie jako swój kres, kres Europy. Oznacza to, że Europa i islam są, dla samej Europy, uwikłane w "grę lustrzanych odbić” stanowiącą „pierwotną relację tożsamościowa, konstytutywną dla europejskości” (63). Relację tę, tożsamą ze źródłową strukturą Europy, badano z wielu perspektyw $[\ldots]^{13}$. Jednak tym, co akcentuje Guénoun i co poddaje oglądowi, nawet jeśli tylko pobieżnemu, jest sposób, w jaki islam został historycznie ukonstytuowany w roli tego, co zewnętrzne, to znaczy tego, co zostało poddane eksterioryzacji. („Musielibyśmy w gruncie rzeczy ująć to tak: islam nie jest zewnętrzny względem naszej historii. Albo też jest zewnętrzny w szczególny sposób: od wewnątrz"; 287.) Islam byłby zatem stawaniem-sięzewnętrznym tego, co znajduje się w „naszym” świecie - „nas, Europejczyków”. (,Zewnętrzność islamu oznacza jego bliskość. Islam w naszej historii to nazwa tej zewnętrzności na wewnętrznej krawędzi naszego świata, która wdziera się przez nią i działa w jej obrębie"; 288.) Jest to szczególnie wyraźne w nowoczesnej konstrukcji islamu jako „fanatyzmu religijnego”, która zbiega się pod względem historycznym z tym, co nadal nazywane jest „sekularyzacja”. Islam staje się więc „wewnętrznym zewnętrzem”, włączonym wyłączeniem, zgodnie ze strukturą wyjątku, która swoją najsłynniejszą formułę znalazła u Carla Schmitta i która będzie dla nas punktem odniesienia pod następującym względem: jeśli „,islam” jest imieniem tego wykluczenia, tego uzewnętrznienia, to „Europa”, określając siebie jako to, co stawia czoła islamowi, ukrywa siebie przed sobą samą, twierdząc, że zyskuje swoje imię i twarz niezależnie od islamu. Ten sposób konstytuowania się Europy jest jednak nie tylko fundamentalnie powiązany z kwestią „religii” i jej podziałami. W nieunikniony sposób niesie on również ze sobą podział na judaizm i islam, rozróżnienie miedzy Żydem i Arabem.

Guénoun jednak, wyjąwszy krótką wzmiankę autobiograficzną, w ogóle nie wiąże tych dwóch postaci ze sobą nawzajem w kontekście ich relacji z Europa. Dlatego też, posługując się

\footnotetext{
${ }^{13}$ Spośród ważnych i modelowych opracowań poświęconych zagadnieniu islamu i Zachodu oraz islamu na Zachodzie wymienić należy: Daniel 1960; Waardenburg 1973; Djait 1985; Said 2009; Grosrichard 1979; Rodinson 1989; Corn 1989; Cardini 2001. [...]
} 
wyłącznie figurą wyłączającego włączenia, odsuwa islam na bok, by zająć się „zasługami Żydów" dla Europy, ani razu nie poruszając przy tym kwestii historycznego powiązania judaizmu z figurą islamu czy islamu z figura judaizmu, w obrębie Europy lub poza nią. A jednak to właśnie figura „zarabizowanego Żyda” (jak określa on własną genealogię) oraz język arabski, którym posługiwali się jego żydowscy przodkowie, każą zadać pytanie, nie mające charakteru wyłącznie historycznego, o warunki tego, co sam pisze, jego własnych ,hipotez na temat Europy”. Jeśli w myśl jego przenikliwych analiz islam jest „,wrogiem zewnętrznym” (to znaczy jeśli się taki stał - stając się zarówno wrogiem, jak i czymś, co zewnętrzne), a judaizm „wrogiem wewnętrznym”, to pytanie, które pozostaje do rozpatrzenia, choć jest ukryte i nieuwzględnione, jest pytaniem o relację między Europa a Żydem i Arabem. Jak zobaczymy, pytanie to stanie się „bardziej radykalne”, kiedy zostanie wyartykułowane w kontekście „refleksji dotyczącej ukonstytuowania się tego, co polityczne, w oparciu podział religijny” (Guénoun 2000, 117, przypis 33). Jest to pytanie zarazem filozoficzne i empiryczne, pytanie, na które składa się nienapisana historia tego, co teologiczno-polityczne, historia wroga.

\section{Wróg, Żyd, Arab}

Ten, kto, na przykład, śmieje się z rasistowskiego żartu [...], nie przychyla się do żadnej tezy, która w tym rejestrze nie zostaje nawet postawiona, ale uznaje to, co istotowe, co nie kieruje się żadnymi argumentami i nie jest ich świadome: że Żydzi czy Arabowie [...] są znakiem poważnego ryzyka: zniszczenia teraźniejszości jako takiej.

Alain David, Racisme et antisémitisme

Potrzebna jest tu uwaga na temat terminologii. Po pierwsze, usiłując podążać wieloma, bez wątpienia ograniczonymi ścieżkami, które mogły doprowadzić mnie do ujęcia kategorii „wroga” w dyskursie filozofii, filozofii polityki oraz nauk politycznych, z zaskoczeniem odkryłem, że istnieją tam tylko rzadkie i okazjonalne, nieobszerne omówienia tej kwestii. Musiałem więc zmierzyć się z czymś w rodzaju zniknięcia wroga, wymazania go z filozoficznej i politycznej refleksji niemal od jej początków, a nie, jak chce Carl Schmitt, dopiero w czasach nowożytnych ${ }^{14}$. O ile zatem można podporządkować kwestię wroga zagadnieniu wojny, należy uznać, że nowożytny dyskurs na temat wojny, zrekonstruowany przez Michela Foucaulta $\mathrm{i}$ innych, zawsze artykułowany jest jako dyskurs historyczno-polityczny (w waskim sensie terminu), nie zaś jako dyskurs filozoficzno-jurydyczny. Dążenie do „odcyfrowania trwałości

\footnotetext{
14 Ważne wyjątki, takie jak: Galison 1994, Buck-Morss 2000, a nawet wcześniejsze od nich: Arendt 2008, nieintencjonalnie zacierają fakt tego zniknięcia.
} 
wojny w społeczeństwie" nie było więc nigdy dążeniem wyłącznie filozoficznym ${ }^{15}$. Nie dotyczy ono też podstawowej różnicy między wojną i wrogiem, nadmiarowości kwestii wroga w stosunku do kwestii wojny ${ }^{16}$.

Jeśli pytanie to - pytanie o wroga - w ogóle się pojawia, staje się głównie zagadnieniem instytucjonalnym, które dotyczy sposobów zachowania się (,jak traktować wroga?”) czy też sposobów działania (,jak walczyć z wrogiem, pokonać go i unicestwić?”), wreszcie - sposobów przejawiania się („oblicza wroga”) oraz identyfikacji („,kto jest naszym wrogiem?”). Wymiar ontologiczny - „czym jest wróg?” - nie pojawia się prawie wcale, a jeśli już, to, [...] tylko po to, by szybko stać się czymś ulotnym, świadectwem zanikania, odsuwania wroga.

${ }^{15}$ Zob. Foucault 1994 i transkrypcja wykładów: 1997/1998. W swoich opublikowanych pracach Foucault, o ile wiem, nie zajmuje się kwestią wroga. Można z nim porównać historyka George’a Mosse'a, który, w odniesieniu do pierwszej wojny światowej, w uderzających słowach opisuje „nadejście nowego rodzaju wojny”. Zmianę tę wiąże z wyłonieniem się nacjonalizmu, a wraz z nim obywatela-żołnierza. Dokumentuje też szereg zmian obejmujących dzieje cmentarzy wojskowych i cywilnych, jak również uogólnione „doświadczenie wojenne”. Jednak z racji nieobecności jakiegokolwiek porównywalnego (bądź porównawczego) omówienia kwestii wroga w książce Mosse’a lub gdzie indziej, należy zachować sceptycyzm co do wagi podobnych, choć ulotnych uwag dotyczących tego problemu (jak pisze Mosse, nie wspominając o Carlu Schmitcie, ,politykę w coraz większym stopniu uznawano za wojnę, która musi się zakończyć bezwarunkową kapitulacją wroga"; Mosse 1990, 161, 163-164 i 172-181).

${ }^{16}$ Związek łączący wojnę i wroga stanowi główny, a przy tym trudny, moment refleksji Carla Schmitta. (Autor jednocześnie podkreśla ten związek i utrzymuje go w zawieszeniu, stwierdzając, że między wrogami, którzy kwestionują nawzajem swoje istnienie, nie musi mieć miejsca żadna rzeczywista walka.) Schmitt najbardziej zbliżył się do napisania historii wroga w Nomos der Erde, gdzie zajmuje się historią prawa europejskiego. Być może najlepiej widać to w jego argumentacji, która głosi, że „prawo rzymskie zdolne było do odróżnienia wroga, hostis, od bandyty i przestępcy" (Schmitt 1950, 22), a także w sposobie, w jaki śledzi wyłonienie się kategorii justus hostis oraz pojawienie się, między osiemnastym i dziewiętnastym wiekiem, wroga jako nieludzkiego, jako Unmensch (72). Widać to również w jego opisach procesu kryminalizacji wroga, który był równoznaczny ze „zniszczeniem pojęcia wroga" (93); a wreszcie także w jego słynnym postulacie zniesienia pojęcia justus hostis jako kategorii należącej do dyskursu teologicznego i politycznego („der Begriff eines justus hostis, kann also [...] angeboben werden”; 143) i w zniknięciu rozróżnienia przyjaciel/wróg opisanego w Pojeciu polityczności.

Jeśli pojęcie wroga istnieje, należy z pewnością do prawa, które przedstawia najspójniejsze jego ujęcie. Pod tym względem prace Richarda Zoucha (1590-1661), do których odwołuje się Schmitt, stanowią wyróżniający się przykład systematycznego i rozstrzygającego uporządkowania kwestii pojęcia wroga. W swoich Elementa jurisprudentiae (ok. 1629) Zouch wprowadza kluczowe rozróżnienie prawne między różnymi rodzajami wrogów: inimici, między którymi nie może zaistnieć żadna więź, zwłaszcza zaś więź prawna; adversarii, należących do jednej wspólnoty prawnej, którą może zniszczyć wojna; hostes to z kolei wrogowie „właściwi”, których można z kolei podzielić na justi hostes i, jeśli powody wojny sa niesprawiedliwe, injustus hostes (zob. Schmitt 1950). Jednak, jak wspomina przelotnie Foucault w swoich wykładach z Collège de France z 1976 roku (1997/1998, przypis 20), kwestia wroga wykracza poza kwestię wojny: „Czy zjawiska antagonizmu, rywalizacji, konfliktu, walki miedzy jednostkami, grupami lub klasami mogą i powinny zostać włączone w ów ogólny mechanizm, w tę ogólną formę, jaka jest wojna?” (Foucault 1998, 54). Rozmaici przeciwnicy, nieraz wręcz wrogowie (ennemi de classe [wróg klasowy], ennemi de race [wróg rasy]; 88; sawvage czy barbare [dzikus czy barbarzyńca]; 194-196; wrogowie „biologiczni” przeciwstawiani „politycznym”; 253) znajdują się w centrum zainteresowania Foucaulta podczas tego cyklu wykładów $(55,60,64,79,95,175)$. Foucault rozpatruje również możliwość, znana już ze średniowiecznej myśli politycznej, że wrogiem może być suweren (60). Nie ma tu jednak żadnej historii wroga, dyskursywnego ujęcia mechanizmu, za pomocą którego wróg zostaje opisany, wytworzony i uruchomiony. Znaczące, choć wąsko zakreślone wyjątki stanowiące wybrane rozdziały z historii wroga to: Buck-Morss 2000 (o zimnej wojnie) i Galison 1994 (o drugiej wojnie światowej). 
Pobieżne przyjrzenie się zachodniej refleksji filozoficznej i politycznej (temu, co dziś nazywa się naukami politycznymi i/lub teorią polityki) ujawnia szybko, że wróg, w przeciwieństwie do przyjaciela czy ukochanego, miłości i przyjaźni (zagospodarowanych przez dyskursy eksperckie filozofii i polityki, ale też etyki, psychologii i innych), nigdy nie staje się pojęciem podstawowym, ani nawet znaczącym pojęciem operacyjnym ${ }^{17}$. Powody dla takich sposobów dyskursywnego wykorzystania terminu wroga, dla uogólnień, którym towarzyszy brak jego konceptualizacji, można znaleźć w filozofii („filozofia, myśląc wojnę, nie myśli nic innego, jak pokój. Myli więc swoje przedmioty [...]. Dlatego dyskurs na temat pokoju staje się, na poziomie filozoficznym, punktem wyjścia dla dyskursu o wojnie. Staje się podziemną podstawą filozofii polityki jako takiej"; Triki 1985, 84) albo też w refleksji politycznej poruszającej kwestię wojny, ale nie wroga, lub, ewentualnie, mówiącej o wrogu (a nawet, jak się wydaje, udzielającej odpowiedzi), ale nie zadającej pytania o niego ${ }^{18}$.

17 „Wróg” może więc stanowić przykład tego, co Catherine Malabou nazywa „symptomem pojęciowym”, narastająca potrzebą „stania się pojęciem”, czy też, inaczej mówiąc, potrzebą uzyskania „statusu warunku zrozumiałości” (Malabou 2000, 7). Kieruję się tu w dużej mierze jej wnikliwymi - i, w rzeczy samej, „wybuchowymi” - analizami formacyjnej, plastycznej historii takiego pojęcia w toku stawania się (opis relacji między historią i plastycznością oraz rozwinięcie tematu formowania się pojęć można znaleźć w: Malabou 1996).

${ }^{18} \mathrm{~W}$ tym miejscu warto przyjrzeć się niedawnemu i bardzo głośnemu przykładowi. W Imperium Michaela Hardta i Antonia Negriego wróg jest zarazem centralny i marginalny, stanowi pojęcie operacyjne, które jest często, choć niekoniecznie w spójny sposób, przywoływane i używane jako podstawa dla dalszych konceptualizacji. („Elementem, który możemy wskazać na poziomie najbardziej podstawowym i elementarnym jest wola bycia przeciw”; Hardt i Negri 2005, 229.) Pozostaje jednak niejasne, czy Imperium tę konceptualizację konstytuuje czy dekonstytuuje. W tym kontekście można powiedzieć za Imperium, że w „Imperium” wróg wcale nie znika, jego faktyczność przekłada się na jego niewidzialność, brak jasności, którego przyczyna jest trwały proces zanikania i który jednocześnie jest domaganiem się jego identyfikacji; proces, który w Imperium zostaje opisany na samym początku jako dwuznaczna banalizacja. „Dzisiaj nieprzyjaciel, podobnie jak sama wojna, zostaje za jednym zamachem zbanalizowany (zredukowany do obiektu rutynowych działań policyjnych) i zabsolutyzowany (jako Wróg, absolutne zagrożenie dla etycznego porządku)" (27). Wrogowie wciąż istnieja, ale wróg jest w coraz mniejszym stopniu nieprzyjacielem w znaczeniu wojennym. Dlatego „wrogowie, którym dzisiaj przeciwstawia się Imperium, mogą stanowić bardziej zagrożenie ideologiczne niż wyzwanie militarne" (50). Zgodnie z tezami książki, wróg w znaczeniu wojennym zanika, wojna się skończyła (jeśli tego chcemy): „Historia wojen imperialistycznych, między-imperialistycznych i antyimperialistycznych skończyła się. Koniec tej historii to początek rządów pokoju. Czy też, w istocie, weszliśmy w epokę mniejszych i wewnętrznych konfliktów. Każda wojna imperialna jest jakaśs wojną domowa, akcją policyjną" (206). A jednak wróg nadal istnieje; nawet organizacje pozarządowe (NGO) mają wrogów, choć nie są to wrogowie wojenni. Są to, co może zaskakiwać, wrogowie teologiczni. Podobnie jak ich religijni poprzednicy, „dominikanie w późnym średniowieczu i jezuici u zarania nowoczesności”, organizacje humanitarne to grupy, które „za pomocą własnego języka i własnego działania najpierw określają wroga jako brak czegoś [...], a następnie traktują wroga jako grzech” (51).

Hardt i Negri ubolewają także nad brakiem precyzji pojęciowej - oraz nad dyskursywnym przemieszczeniem wroga - w odniesieniu do „aktualnych wrogów Imperium”. Imię tego wroga brzmi jednak legion, a retoryka Imperium - retoryka „Imperium” - opisująca problem oscyluje między liczba pojedynczą a mnoga (pod przywództwem USA uruchamiany zostaje „proces zbrojnego powstrzymywania i/lub represjonowania aktualnych wrogów Imperium. Wrogowie ci najczęściej nazywani są terrorystami, co jest grubą redukcją pojęciową i terminologiczną, która ma swe korzenie w mentalności policyjnej”; 52). Niektórzy mylą się co do wroga i maskują go w ten sposób (na przykład „strategia oporu lokalnego”; 62); wymaga to więc korekty. Włączając się w nieokreśloną i pełną ambiwalencji walkę z „postmodernizmem”, Hardt i Negri ubolewają nad faktem, że „postmoderniści [...] wciąż jeszcze toczą bój z cieniami dawnych przeciwników”: „Podejrzewamy, że teorie postmodernistyczne i postkolonialistyczne $[\ldots]$ nie rozpoznają dostatecznie współczesnego przedmiotu krytyki, a zatem błędnie rozpoznają rzeczywistego przeciwnika” $(158,154)$. Istnieje ,nowy przeciwnik”, nie tylko 
Powody opisanego wyżej stanu rzeczy (stanu pytania o wroga) mogą być tak czy inaczej liczne; niezwykle trudne jest utrzymanie perspektywy zdolnej ustanowić ciagłość wroga, pojęcia wroga, a tym bardziej pozwalającej także dowodzić i wykazywać epistemiczne przesunięcia, zerwania, zmiany strategiczne czy linearne mutacje w historii wroga ${ }^{19}$. Co więcej, pozostaje niejasne, na ile sam termin „wróg” ma w ogóle, we wszystkich językach, w jakich się tutaj pojawia (głównie angielskim, niemieckim i francuski, a w pewnej mierze w grece i łacinie), jakąś domniemaną tożsamość semantyczna, która mogłaby go uzasadnić.

To, co może wydawać się filologiczną niejasnością czy brakiem filozoficznego rygoru, kształtowane jest, czy wręcz dyktowane, przez znikanie, nacisk na usuwanie (które nie jest tożsame z nieobecnością) wroga z każdej uprzywilejowanej sfery dyskursywnej. Czy pytanie o wroga jest pytaniem filozoficznym, prawnym czy psychologicznym? Czy jest pytaniem uwarunkowanym kulturowo, historycznym czy (wreszcie) politycznym? Poza podjęta przez Carla Schmitta próbą nie tyle odnowienia, co ustanowienia pojęcia wroga i nadania decyzji

„odporny na stare rodzaje broni, lecz faktycznie korzysta[jący] z nich, przyłączając się do swych rzekomych antagonistów” (155). Dążąc do likwidacji tego błędnego podejścia, „musimy wyraźnie zdawać sobie sprawę, jaka forma władzy służy w tym postkolonialistycznym myśleniu za przeciwnika” (161). Powinniśmy też, przede wszystkim, umieć rozpoznać prawdziwego wroga. „Dzisiaj pierwszym pytaniem filozofii politycznej nie jest czy, ani nawet dlaczego, dojdzie do oporu i buntu, lecz raczej: jak określić wroga, przeciwko któremu należy się zbuntować? Często bowiem to właśnie niezdolność do zidentyfikowania wroga prowadzi wolę oporu do takich paradoksalnych wolt. Identyfikacja przeciwnika nie jest jednak łatwym zadaniem [...]” (229).

Jest ona niełatwym zadaniem, ponieważ „doświadczamy wyzysku, alienacji i władzy jako wrogów, ale nie wiemy, gdzie lokować wytwarzanie stosunków opresji” (229). Rzeczywistym wrogiem jest, jak piszą nasi autorzy, „pewien szczególny reżim stosunków globalnych, który nazywamy Imperium” (62). Wróg jest obecny, ale jest także czymś nowym, nadchodzacym. Wciąż jest jeszcze przed nami, dlatego można afirmować zadanie polegające na stawieniu czoła (właściwemu) wrogowi jako konieczny krok, który jest przed nami. „Określenie wspólnego wroga i wynajdywanie wspólnego języka są z pewnością ważnymi zadaniami politycznymi i będziemy je realizować w tej książce jak dalece to możliwe" (73). W Imperium wróg jest więc przedmiotem narzekań (nie wiemy już, kim jest wróg, pomyliliśmy się co do wroga), ale także rozpoznaje się go, a nawet wzywa i pragnie. Wróg jest jednocześnie nie dość skonceptualizowany i nadmiernie skonceptualizowany. Jest tak, jakbyśmy zdążyli mieć już dosyć myślenia o nim. Mamy wroga - czy też będziemy go mieli i będziemy musieli go mieć - a naglącym pytaniem jest: co mamy z nim zrobić? Czy ściślej: co mamy zrobić jemu? „Problemem, z którym teraz musimy się zmierzyć, jest to, jak mogą się faktycznie pojawić konkretne przykłady walki klasowej, a nadto jak mogą one kształtować spójny program walki, siłę konstytuującą wystarczającą do zniszczenia przeciwnika i zbudowania nowego społeczeństwa" (424). Nieprzypadkowo, jak zobaczymy w następnym rozdziale, zadanie to - zadanie zniszczenia wroga - bierze za swój wzór miłość chrześcijańską. To dlatego pod koniec Imperium chrześcijańska walka świętego Franciszka z Asyżu „czyni opór kontr-władza, a bunt projektem miłości” (433).

${ }^{19}$ Podobnie jak Heglowski Bóg, tak uderzająco opisany przez Malabou, wróg może być widoczny tylko przez moment i jako moment - moment teologiczno-polityczny. Autorka ujmuje to w jednym niezwykle mocnym zdaniu: „Dieu se voit un moment'. Pożyczając jej sformułowania i podażając za jej rozważaniami na temat momentu, możemy pokusić się o to, co następuje: po pierwsze, wróg widziałby siebie i ukazywał się przez moment w wyjątkowej i niepowtarzalnej chwili i przypadku (exemple). Albo też widziałby siebie i ukazywałby się przez pewien okres, nawet w pewnej epoce, choć tak czy inaczej przez pewien (bardziej lub mniej ograniczony) czas, istniejac tym samym w czasie. Zgodnie z trzecim sensem wróg widziałby siebie i ukazywałby się jako moment: o ile wróg widzi siebie, widzi swoje odbicie jako moment. „Moment” staje się w ten sposób atrybutem wroga, który postrzega siebie qua moment. Na koniec, w sensie logicznym, stawanie-się-widzialnym wroga jest tożsame $\mathrm{z}$ jego stawaniem się $\mathrm{w}$ ogóle, $\mathrm{z}$ momentem jego istoty, którą realizuje, stając się, z jego stawaniem się jako stawaniem-się-momentem (Malabou 1996, 299). 
dotyczącej rozróżnienia miedzy wrogiem i przyjacielem statusu warunku polityczności, poza przełomowymi refleksjami Jacques'a Derridy na temat wroga w Politiques de l'amitie, niewiele pozwala nam uzasadnić czy choćby uprawdopodobnić tezę, że uda się nam kiedykolwiek napisać historię wroga ${ }^{20}$. Wróg zatem znika po raz kolejny, pozostawiając po sobie pytanie: „dlaczego”, a być może i pytanie: ,jak?”.

Jakie procedury i modalności sprawiają, że historia wroga stała się niemożliwa? Niniejsza książka ma za zadanie pokazać, że owa historyczna niemożność zależna jest od tego, co warunkuje religię i politykę w „Europie”, a więc od warunku, który opisał Derrida w swoich tekstach poświęconych temu, co Abrahamowe ${ }^{21}$. Nic nie usprawiedliwia utożsamiania religijnych (i historycznie watpliwych) znaczników takich jak judaizm i islam ze znacznikami etnicznymi czy politycznymi, takimi jak Arab czy Żyd. Jednak asymetria między tymi terminami (,żyd” i „muzułmanin”, „Żyd” i „Arab”) podtrzymywana jest przez historię, która dąży do wyjaśnienia procesu ich kształtowana się jako spolaryzowanych tożsamości. To, co wydawało się wyborem czysto leksykalnym, w rzeczywistości nigdy nim nie było (nawet jeśli używanie terminu „Arab”, z jego naciskiem na wymiar językowy, sprawia, że paradoksalnie trudno jest

${ }^{20}$ Co ciekawe, w Nomos der Erde Schmitt rekonstruuje tak naprawdę działanie czegoś zbliżonego do pojęcia wroga w sferze prawa. Jednak takie ograniczenie tego pojęcia do dziedziny prawa wydaje się tylko umacniać powszechny brak refleksji filozoficznej i politycznej na jego temat. W dalszych częściach książki poruszę kwestię nieobecności „ontologicznego pytania” o wroga, na którą zwrócił uwagę już Derrida. Na razie wystarczy zasygnalizować, że jest to właśnie pytanie, które chwieje się i wycofuje w tekście Schmitta, pojawiając się i znikając w zależności od tego, jak zinterpretujemy owo they pojawiające się w błędnym cytacie z The Education of Henry Adams pod koniec Nomos der Erde: ,if the foe is not what they say he is, what are they?” [,jeśli wróg nie jest tym, czym oni mówia nam, że jest, czym są oni?”; Schmitt podaje ten cytat w postaci: ,if the foe was not what they said he was what were they?'] (Schmitt 1950, 299).

Powinno być jasne, że omówienie tej kwestii w Politiques de l'amitie Derridy jest kluczowe dla próby podjętej w niniejszej książce. Chciałbym podkreślić zwłaszcza znaczenie powyższej wypowiedzi: „To, co mówi się o wrogu, nie jest symetryczne wobec tego, co możemy powiedzieć o przyjacielu, nawet w kontekście strukturalnych czy wspólnych warunków możliwości" (Derrida 1994/2005, 122). William Desmond odnotowuje, że o wrogach i wrogości napisano jak dotąd bardzo niewiele. Jak zauważa na początku własnych dociekań, „[n]iektórzy myśliciele pisali o wojnie, inni, jak Friedrich Nietzsche czy Carl Schmitt, o potrzebie istnienia wroga. Ale kto pisał o naturze wroga w sposób analogiczny do pisania o naturze miłości? O ile wiem, niewielu" (Desmond 2001,127). Desmond, podobnie jak Schmitt, określa stawkę bardzo wysoko („a jeśli nie wiemy, czym jest wróg, czy wiemy, czym jest przyjaciel?’); mimo to, sugerując już na początku symetrię między wrogiem i przyjacielem, a nawet między wrogością i miłościa (pierwsza ma być „odwróceniem, negacja”” drugiej), narzuca ograniczenia temu, co ma być badane. Jak ujmuje to Kant w Wyktadach z etyki, „,wrogość to coś więcej niż brak przyjaźni”" (Kant 1997, 190). Desmond nie porusza też w ogóle kwestii wroga politycznego i nie ma nic do powiedzenia na temat wojny. Jak twierdzę, zagadnienia wroga nie da się zredukować do zagadnienia wojny, nawet jeśli jest ono od niego zależne, co można ująć, na innym poziomie analizy, dzięki temu, co Vilho Harle określa mianem „obecnego zainteresowania badaczy zajmujących się pokojem kulturą i językiem oraz ich związkami z zagadnieniami pokoju i wojny". Na podstawie zawartości redagowanego przed niego numeru specjalnego History of European Ideas [Harle 1991 - przyp. tłum.] trudno jednak określić, co ma na myśli, pisząc, że „badacze ci poświęcili wiele energii rozpatrzeniu problemu wroga”, albo jakie „pojęcia” wroga, poza tym Schmittowskim, biora pod uwage zgromadzeni przez niego badacze. Zawarte w numerze artykuły dotycza postaci takich jak Eliade, Arendt i Schmitt, „psychologii wrogości” czy „obrazu Europy w rosyjskiej literaturze i kulturze”. Abstrahując od tekstów samego Schmitta, trudno uznać, by te interesujące pod wieloma względami artykuły wykorzystywały dobrze opracowane „pojęcie” wroga (Harle 1991, 333; Harle 2000 i Buck-Morss 2000).

${ }^{21}$ Zob. Derrida 2002 i rozdział 2 niniejszej ksiażki: „Derrida, the Jew, the Arab”. 
po prostu przeciwstawić go terminowi „Żyd”, którego religijna historia pozostaje nieco bardziej widoczna). Już samo podążanie za wątłą tradycja, która tak niejasno, czy wręcz osobliwie mówi o „symbiozie żydowsko-muzułmańskiej” (zawsze poza Europa, tak jakby symbioza ta nie miała z nią nic wspólnego), oznaczałoby decyzję o umieszczeniu problemu w sferze religii, jakkolwiek dość szeroko zdefiniowanej. Byłoby to też równoznaczne z pominięciem faktu, że poza bardziej lub mniej ograniczonymi obszarami synkretyzmu obydwie te „religie” - jeśli rzeczywiście są to religie - musiały jako systemy praw (dat po hebrajsku, din po arabsku) pozostać odrębne, lub przynajmniej dążyć do tej odrębności z powodów pragmatycznych czy też, jak powiedzielibyśmy dziś, ze względów bezpieczeństwa. Jest dziś czymś banalnym, choć także nie do końca ścisłym, skupianie się na przykładzie arabskich chrześcijan, którzy (niezależnie od różnic religijnych i ponad nimi) stanowia grupę powszechnie rozpoznawana jako zarazem odrębna i nie-odrębna (pod różnymi względami charakterystycznymi dla danego obszaru) od muzułmańskiej populacji arabskiej oraz powiązana w sposób, którego nie potrafi ująć żadna kategoria w rodzaju „symbiozy chrześcijańsko-muzułmańskiej”. A zatem - „Żyd, Arab", ponieważ zagadnienie to jest skomplikowane i wielowymiarowe, a żeby opisać terminologiczne możliwości i niemożliwości, potrzeba wielu narzędzi analitycznych ${ }^{22}$.

Istnieje jednak jeszcze jeden powód, by przywoływać „Żyda, Araba” w wielu kontekstach historycznych, do których odnosi się ta książka. Jest to powód historyczny: „Europa”, o której można powiedzieć, że od dawna myli poszczególne terminy, że utożsamia ze sobą Arabów i muzułmanów, ludzi Orientu i Semitów, Turków i Saracenów, stanowi miejsce, niepewne i sfragmentaryzowane, w którym te dwie postaci wyłaniają się jako wrogowie; wrogowie

\footnotetext{
${ }^{22}$ Steven Wasserstrom (który wykroczył daleko poza swój wyjściowy obszar kompetencji) przedstawia ujęcie dość pouczające i reprezentatywne dla dziedziny, która pozostaje pod wieloma względami marginalna, zdając sprawę ze stanu badań na temat „Żydów w islamie” i tak zwanej „symbiozy żydowsko-muzułmańskiej” (Wasserstrom 1992). Opisuje on problemy związane z badaniem owej „symbiozy” jako natury praktycznej i metodologicznej (3-14). Słusznie identyfikując prace Schlomo D. Goitena (1974) i Bernarda Lewisa (1987) jako źródło popularności wspomnianego terminu, nie problematyzuje jednak kwestii obszaru „religii”, w którym umieszcza swój przedmiot, nie przedstawia też żadnych powodów dla takiego ograniczającego umiejscowienia i wcześniejszego braku tych powodów. (Wasserstrom jednoznacznie stwierdza, że jego dociekania sytuuja się na obszarze „religioznawstwa porównawczego” i „relacji międzyreligijnych”, słusznie zwracając uwagę na niewystarczający charakter wcześniej podejmowanych na tym terenie badań: „badania religioznawcze ledwo zaczęły stawiać problem niezwykłego zjawiska symbiozy żydowsko-muzułmańskiej, tym bardziej zaś nie zaczęły w ogóle kwestionować samego ich paradygmatu"; Wasserstrom 1992, 7.) W dodatku nie pyta on o dystans, który zostaje z góry założony, ustanowiony i utrwalony przez słowa, przede wszystkim zaś przez słowo „pomiędzy”. Mówiąc ogólniej, Wasserstrom nie bierze pod uwagę znaczenia języka (własnego, jak również języka swoich „obiektów badań”) i jego roli w ujęciu tego, co nazywa „problemem” (podtytuł jego książki brzmi „Problem symbiozy we wczesnym islamie"). Chodzi tu o coś więcej niż kontrowersję terminologiczną dotycząca użycia słowa „symbioza”; chodzi o kwestię relacji Araba (oraz tego, co arabskie) i muzułmanina (co znaczy „Arab, muzułmanin”, a co, w końcu, słowo ,i”’?) oraz Araba i Żyda. Wasserstrom prawie nie porusza kwestii wspólnego języka „Żydów” i „muzułmanów” - arabskiego. (Dlatego dopiero w połowie książki zauważa, że w średniowieczu „teologie żydowskie i muzułmańskie [a w gruncie rzeczy i wszystkie pola dyskursywne - G.A.], tworzone w języku arabskim, oczywiście pokrywały się w znacznym stopniu"; 145.) Nie zajmuje się też w ogóle przesunięciem leksykalnym prowadzącym od Jews and Arabs [,Żydów i Arabów”] Goitena do Jews of Islam [,Żydów w islamie”] Lewisa. Dystans pomiędzy muzułmaninem a Żydem nigdy się nie zmniejsza. A Arab usuwa się w cień.
} 
Europy i swoi nawzajem. „Żyd”, „Arab” to z pewnością określenia arbitralne. Są to jednak również dawne określenia, które w strategiczny i stanowczy sposób wyznaczyły niedostrzeganą na razie konieczność historyczną - dotycząca historii teraźniejszości par excellence - Europy i Zachodu. A zatem - „Żyd, Arab”. A także - jeśli jest ona w ogóle możliwa - historia wroga. 


\section{Wykaz literatury}

Allouche-Benayoun, Joëlle, Doris Bensimon. 1997. „Juifs d'Algérie hier et aujourd'hui”. Annales de géographie 557.

Arendt, Hannah. 2008. Korzenie totalitaryzmu. Tłum. D. Grinberg i M. Szawiel. Warszawa: Wydawnictwa Akademickie i Profesjonalne.

Arystoteles. 1988. Poetyka. W Arystoteles. Retoryka, Poetyka. Tłum. H. Podbielski. Warszawa: PWN.

Buck-Morss, Susan. 2000. Dreamworld and Catastrophe: The Passing of Mass Utopia in East and West. Cambridge, Mass.: MIT Press.

Cardini, Franco. 2001. Europe and Islam. Tłum. C. Beamish. Oxford: Blackwell.

Choraqui, André. 1973. Between East and West. A History of the Jews in North Africa. Tłum. M. M. Bernet. New York: Atheneum.

Corn, Georges. 1989. L'Europe et l'Orient: De la balkanization a la libanisation-Histoire d'une modernité inaccomplie. Paris: La decouverte.

Daniel, Norman. 1960. Islam and the West: The Making of an Image. Edinburgh: Edinburgh University Press.

David, Alain. 2001. Racisme et antisémitisme. Essai de philosophie sur l'envers des concepts. Paris: Ellipses.

Derrida, Jacques. 2001. „Above All, No Journalists!”. Tłum. S. Weber. W Religion and Media. Red. Hent de Vries i Samuel Weber. Stanford: Stanford University Press.

Derrida, Jacques. 2002. Acts of Religion. Red. G. Anidjar. New York-London: Routledge.

Derrida, Jacques. 2017. Inny kurs. Tłum. T. Załuski. Warszawa: PWN.

Derrida, Jacques. 1996. Le monolingualisme de l'autre. Paris: Editions Galilée.

Derrida, Jacques. 1994. Politiques de l'amitié. Paris: Editions Galilée/2005. The Politics of Friendship. Tłum. G. Collins, London: Verso.

Desmond, William. 2001. „Enemies”. Tijdschrift voor Filosofie 63.

Djaït, Hichem. 1985. Europe and Islam: Cultures and Modemity. Tłum. P. Heinegg, Berkeley: University of California Press.

Foucault, Michel. 1994. „Il faut défendre la sociéte”. W Michel Foucault. Dits et écrits III (1976-1979). Paris: Gallimard.

Foucault, Michel. 1997. Il faut défendre la sociéte: Cours au Collège de France (1975-1970). Paris: Seuil/Gallimard/1998. Trzeba bronić spoteczeństwa: wykłady w Collège de France. Tłum. M. Kowalska. Warszawa: KR.

Galison, Peter. 1994. „The Ontology of the Enemy: Norbert Wiener and the Cybernetic Vision". Critical Inquiry 21/1.

Gasché, Rodolphe. 2000. „The Debt of Europe”. W Future Crossings: Literature Between Philosophy and Cultural Studies. Red. K. Ziarek i S. Deane. Evanston: Northwestern University Press. 
Goiten, Schlomo D. 1974. Jews and Arabs. Their Contacts through the Ages. New York: Schocken.

Grosrichard, Alain. 1979. Structure du serail: La fiction du despotisme asiatique dans l'Occident classique, Paris: Seuil/1997. The Sultan's Court: European Fantasies of the East. Tłum. L. Heron. London: Verso.

Guénoun, Denis. 2000. Hypotheses sur l'Europe: Un essai de philosophie. Belfort: Circe.

Halevi, Ilan. 1987. A History of the Jews: Ancient and Modern. Tłum. A. M. Berrett, London: Zed Books.

Hardt, Michael i Antonio Negri. 2005. Imperium. Tłum. S. Ślusarski i A. Kołbaniuk. Warszawa: W.A. B.

Harle, Vilho. 2000. The Enemy with a Thousand Faces: The tradition of the Other in Western Political Thought and History. Westport, CT-London: Pareger.

Harle, Vilho (red.). 1991. „Concepts of the »Enemy« in European Thought”. History of European Ideas 13/4.

Kant, Immanuel. 1997. Lectures on Ethics. Tłum. P. Heath. Red. P. Heath i J.B. Schneewind. Cambridge: Cambridge University Pres.

Lewis, Bernard. 1987. The Jews of Islam. Princeton: Princeton University Press.

Lewis, Bernard. 1999. Semites and Anti-Semites: An Inquiry into Conflict and Prejudice. New York: W. W. Norton.

Malabou, Catherine. 1996. L'avenir de Hegel: Plasticité, temporalité, dialectique. Paris: Vrin.

Malabou, Catherine. 2000. „Ouverture: Le voeu de plasticité”. W Plasticité. Red. C. Malabou. Paris: Léo Scheer.

Mamdani, Mahmood. 2001. When Victims Become Killers. Colonialism, Nativism, and the Genocide in Rwanda. Princeton: Princeton University Press.

Massad, Joseph. 2001. Colonial Effects: The Making of National Identity in Jordan. New York: Columbia Univerity Press.

Mosse, George. 1990. Fallen Soldiers. Reshaping the Memory of the World Wars. New York: Oxford University Press.

Nancy, Jean-Luc. 1998. „La Déconstruction du Christanisme”. Les etudes philosophiques 4/2001. „The Deconstruction of Christianity”. Tłum. S. Sparks. W Religion and Media. Red. H. de Vries i S. Weber. Stanford: Stanford University Press.

Rodinson, Maxime. 1989. La fascination de l'islam. Paris: La decouverte.

Triki, Fathi. 1985. Les philosophes et la guerre. Tunis: Publications de l’Université de Tunis.

Raz-Krakotzkin, Amnon. 2002. „A National Colonial Theology - Religion, Orientalism, and the Construction of the Secular in the Zionist Discourse". Tel Aviver Jabrbüch für deitsche Geschichte 30, 321.

Raz-Krakotzkin, Amnon. 2001. „Binationalism and Jewish Identity: Hannah Arendt and the Question of Palestine”. W Hannah Arendt in Jerusalem. Red. S. Aschheim. Berkeley: University of California Press. 
Raz-Krakotzkin, Amnon. 1998. „A Peace without Arabs. The Discourse of Peace and the Limits of Israeli Consciousness". W After Oslo. New Realities, Old Problems. Red. G. Giacaman i D. Jorund Lonning. London: Pluto Press.

Rodrique, Aron. 1993. Images of Sephardi and Eastern Jewries: The Teachers of the Alliance Israélite Universelle, 1860-1939. Seattle: University of Washington Press.

Said, Edward. 2009. Orientalizm. Tłum. W. Kalinowski. Warszawa: PIW.

Schmitt, Carl. 1950. Nomos der Erde:Völkerrecht des Jus Publicum Europaeum. Köln: Greven Verlag.

Waardenburg, Jean-Jacques. 1973. Islam dans le mirroir de l'occident. Paris: Mouton.

Wasserstrom, Steven M. 1992. Between Muslim and Jew: The Problem of Symbiosis under Early Islam. Princeton: Princeton University Press. 
Gil Anidjar - profesor na Wydziale Studiów nad Religią oraz na Wydziale Studiów Bliskowschodnich, Południowoazjatyckich i Afrykańskich (MESAAS), a także w Instytucie Porównawczej Literatury i Społeczeństwa (ICLS) na Uniwersytecie Columbia.

\section{DANE ADRESOWE:}

Columbia University

212-851-4130

Office Hours:

Tuesdays 2-4pm

Room 207

80 Claremont

EMAIL: ga152@columbia.edu

CYTOWANIE: Anidjar, Gil. 2017. „Żyd, Arab. Historia wroga.” Praktyka Teoretyczna 4(26): 94-117

DOI: $10.14746 /$ prt.2017.4.4

\section{AUTHOR: Gil Anidjar}

TITLE: The Jew, the Arab: A History of the Enemy

ABSTRACT: The text is a fragment of a book titled The Jew, The Arab: A History of the Enemy, which is devoted to the history of hostility between Arabs and Jews, as well as to the connection of this conflict with the shaping of both identities in Europe and the identities of Arabs and Jews themselves. Following considerations by such philosophers as Carl Schmitt and Jacques Derrida, the author tries to present the mechanisms responsible for creating primary differences as the necessary conditions for identity creation. These differences are essential for creating conceptual pairs such as "inside-outside" or "enemy-friend." The problem of constructing a concept of the enemy as well as of forging differences and identities is examined at the crossroads of theology, politics, law and ethnic differences, as well as in its function in the very creation of the concept of "Europe."

KEYWORDS: anti-Semitism, islamophobia, colonialism, difference, Europe, orientalism, Derrida, theology, law 